\title{
Racial Differences in Sensitivity to Behavioral Integrity: Attitudinal Consequences, In-Group Effects, and "Trickle Down" Among Black and Non-Black Employees
}

Tony Simons

Cornell University

Ray Friedman

Vanderbilt University

Leigh Anne Liu

Georgia State University

Judi McLean Parks

Washington University in St. Louis

Recent research has suggested that employees are highly affected by perceptions of their managers' pattern of word-action consistency, which T. Simons (2002) called behavioral integrity (BI). The authors of the present study suggest that some employee racial groups may be more attentive to BI than others. They tested this notion using data from 1,944 employees working at 107 different hotels and found that Black employees rated their managers as demonstrating lower BI than did non-Black employees. Mediation analyses were consistent with the notion that these differences in perceived BI in turn account for cross-race differences in trust in management, interpersonal justice, commitment, satisfaction, and intent to stay. Results of hierarchical linear modeling were consistent with the idea that middle managers' perceptions of their senior managers' BI "trickle down" to affect line employee perceptions of the middle managers and that this trickle-down effect is stronger for Black employees. The authors interpret these results as indicative of heightened sensitivity to managers' BI on the part of Black employees. They also found a reverse in-group effect, in that Black employees were substantially more critical of Black managers than were non-Black employees.

Keywords: behavioral integrity, trust, diversity and race, trickle down, justice 
Simons (2002) defined behavioral integrity (BI) as "the perceived pattern of alignment between an actor's words and deeds" (p. 19). It includes the perceived match between espoused and enacted values and also the extent to which promises are seen as being kept. BI is a trait ascribed to the manager and, as such, entails an internal attribution for the observed pattern. BI has been theorized to affect employee citizenship behavior (Simons, 2002) and willingness to support change (Simons, 1999). Simons and McLean Parks (2000) found that BI was associated with trust in managers and organizational commitment, which in turn were associated with employee retention, customer service, and company profitability. BI as a distinct construct has been shown to have important consequences, both as a main effect and as a moderator of the impact of supervisory guidance on employee conduct (Dineen, Lewicki, \& Tomlinson., 2006).

Subjective perception and interpretation processes play a critical role in the BI construct, as it is in no small part "in the eye of the beholder." Thus, it makes sense to consider that different employees will read different levels of BI within a given organizational context. According to Simons (2002), an employee's sensitivity to a manager's word- deed alignment is moderated by a number of factors, including the employee's degree of vigilance and priming and "chronic schema accessibility" (Fiske \& Taylor 1991), which in this context is the extent to which the observer habitually assesses integrity. These factors, we argue, suggest that Black employees will be more likely to notice and be affected by managers' word- deed misalignments than will nonBlack employees.

We focus here on Blacks, and not minorities in general, because the Black experience in America has been, and continues to be, especially distinct (Hacker, 1992) and because barriers to upward mobility within organizations are especially strong (Cancio, Evans, \& Maume, 1996; Davis \& Watson, 1982; Demaris \& Yang, 1994; Dickens \& Dickens, 1982; Irons \& Moore, 1985; Maume, 1999). We argue that Blacks have historically based reasons to be especially vigilant to hypocrisy by those in power and thus may be especially sensitive to word-action misalignment. If absolute wordaction alignment is an ideal that is seldom attained by any manager, then this heightened sensitivity may translate to more negative BI perceptions by Black employees observing those managers. Davidson and Friedman's (1998) vignette studies found evidence of a "persistent injustice effect," whereby Black employees are more likely to notice unjust treatment of other Black employees and to be more skeptical of managers' proffered accounts for the injustice. They explain the effect as emerging from observers' identification with the victim and personal experience with injustice. We build on this stream of research by examining Black employees' perceptions in a real workplace and by further articulating the mechanisms whereby race affects perception and attitude.

In this article, we examine cross-race differences in BI perceptions and test them with data from 1,944 employees in 449 different departments at 107 hotels across the United States. We examine possible consequences of these differences and explore 
whether the differences emerge primarily from differential treatment on the part of management or from differential perception processes on the part of employees.

\section{Behavioral Integrity}

Managers often espouse values like participation or quality, but their actions are sometimes seen as falling short of their espousal. For example, most academics have, at some time, experienced a dean's verbal description of research as a top priority, coupled with increased demands or incentives for teaching and/or no additional material support for the desired activity. Airline reservation agents hear their managers talk about the critical importance of customer service while they are asked to enforce overbooking policies that clearly do not put the customer first. Whereas such apparent inconsistencies often result from managers' pursuit of multiple objectives and their efforts to accomplish more with fewer resources, Meglino and Ravlin (1998) pointed out that values, by definition, state what is more important-they are priorities. From this perspective, patterns of espousal of one value coupled with actions that strongly support another are likely to be seen as misrepresentations of actual values or as failures to live up to espousals. Discrepancy between managers' words and deeds has been discussed in academic literature (e.g., Brunsson, 1989; March, 1979; Meyer \& Rowan, 1977; Pfeffer, 1992; Weick, 1995) and practitioner literature (e.g., Foy, 1985; Kouzes \& Posner, 1993; Tate, 1996), and it is universally decried as damaging to the employment relationship.

Simons (2002) argued that BI differs from common conceptualizations of trust, as trust typically includes affective components (e.g., Kramer, 1996), other judgments such as benevolence (e.g., Cummings \& Bromiley, 1996), and behavioral intentions (e.g., Mayer, Davis, \& Schoorman, 1995). Interpersonal justice (Bies \& Moag, 1986; Greenberg, 1990) may include BI but also includes additional judgments of interpersonal sensitivity, courtesy, and respect. BI is, however, a central antecedent to both trust and justice perceptions. The "promise-keeping" component of BI evokes psychological contracts (Rousseau \& McLean Parks, 1993). However, BI differs in that it is affected by judgments about words and actions aimed at parties other than the self and by judgments about both concrete and abstract managerial espousals that cynical employees may never have taken seriously as part of a reciprocal set of expectations. Psychological contract violations may be considered as especially salient and egregious word-action misalignments that would almost certainly cause the observer to downgrade the ascribed BI of the actor. However, BI differs fundamentally in that it is an ascribed trait of the manager rather than an implicit or explicit set of reciprocal obligations (Shore et al., 2004). The relationships between BI and related constructs is discussed in greater detail in Simons (2002).

Like justice, BI is perceived as an intrapsychic phenomenon that is subjectively determined (Simons, 2002). As such, like justice, it is strongly affected by the mental structures and expectations held by the perceiving party (Schminke, Ambrose, \& Noel, 
1997). It is also true of BI that, like justice, there is an objective element to which the perceiver reacts (Schminke, Ambrose, \& Cropanzano, 2000). It is useful, from both a prescriptive and a research standpoint, to distinguish the intrapsychic and objective elements of the final perceived construct-BI. Managers' actual pattern of word- deed alignment would comprise some function of all the manager's words, all his or her deeds, and an assessment, within the relevant cultural contexts, of the symbolic meaning attached to each. A useful approximation of that actual pattern may be derived by aggregation of the perceptions of relevant stakeholders. BI starts with a perceiver's exposure to a sample of the manager's words and actions and is by definition filtered through a perceptual lens. For the purpose of rigorous theory, it is only called BI when it is perceived. The objective pattern of a manager's word-deed alignment is, one can reasonably assert, an important antecedent to BI, which is the perceived pattern.

A construct validation study, performed with an independent sample of 1,666 hotel employees, provided support for the present application of the BI construct. Scale reliabilities were strong for both English $(\alpha=.96, n=1,219)$ and Spanish $(\alpha=.94, n=$ 322 ) written surveys and for the oral administration offered to illiterate employees ( $\alpha=$ $.96, n=125$ ). The results of both exploratory and confirmatory factor analysis were consistent with a unidimensional construct. We then assessed the distinction between $\mathrm{BI}$ and the closely related construct of trust. The results of both exploratory and confirmatory factor analyses were consistent with a distinction between the two. We then endeavored to integrate BI with the nomological network by examining convergent and discriminant validity. To this end, we selected nine comparison variables that we believed would be related to BI at varying levels. Specifically, we examined the relationship between BI and trust in one's manager, satisfaction with supervision, interpersonal justice, procedural justice, commitment, and satisfaction with pay, benefits, the work itself, and coworkers. We hypothesized that the strongest relationship should be found with trust in one's manager, satisfaction with one's manager, and interpersonal justice. Our logic in making this prediction is based on the more proximate cause of the manager's actions on perceptions of BI, on the central role of $\mathrm{BI}$ in determining trust and interpersonal fairness, and on the roles of trust and interpersonal fairness in driving satisfaction with supervision (e.g., Masterson, LewisMcClear, Goldman, \& Taylor, 2000). We expected more moderate, but significant, relationships with procedural justice and commitment, whereas we expected that satisfaction with one's pay, benefits, the work itself, and coworkers would be relatively

Table 1

Correlations of Key Constructs With Behavioral Integrity

\begin{tabular}{|c|c|c|c|c|}
\hline Construct & $r$ & No. of items & Reliability & Source \\
\hline \multicolumn{5}{|l|}{ Expect strong correlation } \\
\hline Trust in manager & .70 & 3 & .84 & Original to present research \\
\hline Satisfaction with supervision & .66 & 3 & .83 & Hackman \& Oldham (1975) \\
\hline Interpersonal justice & .60 & 4 & .89 & Modified from Niehoff \& Moorman (1993) \\
\hline \multicolumn{5}{|l|}{ Expect moderate correlation } \\
\hline Procedural justice & .58 & 4 & .83 & Modified from Niehoff \& Moorman (1993) \\
\hline Commitment & .56 & 6 & .92 & Mowday, Steers, \& Porter (1979) \\
\hline \multicolumn{5}{|l|}{ Expect weaker correlation } \\
\hline Satisfaction with pay & .40 & 2 & .86 & Hackman \& Oldham (1975) \\
\hline Satisfaction with benefits & .36 & 4 & 69 & Original to present research \\
\hline Satisfaction with work & .54 & 4 & .78 & Hackman \& Oldham (1975) \\
\hline Satisfaction with coworkers & .39 & 2 & .67 & Hackman \& Oldham (1975) \\
\hline
\end{tabular}


weak, perhaps affected only by a spillover effect of satisfaction with supervision. These correlations and descriptions, and the reliabilities associated with each scale, are shown in Table 1 . The results of this analysis are almost entirely consistent with hypothesized relationship strengths. This empirical demonstration of relationships between BI and existing constructs allows for more confident inference based on research done using these related constructs.

\section{Race as an Amplifier of BI Concerns}

If perception and interpretation processes play an important role in the mechanisms by which word-deed alignment affects organizational functioning, then socalled "observer effects" warrant study. Simons (2002) argued that employees' BI perceptions of their managers will be affected by several factors. Some people may be personally more sensitive to BI-they simply care about BI more than others do and judge people in terms of BI. In such cases, BI, or an analogous construct like hypocrisy, is "chronically accessible" to that observer (Fiske \& Taylor, 1991), which is likely to affect vigilance regarding misalignment. Also, prior expectations, or "perceptual priming" (Fiske \& Taylor, 1991) will lead some observers to look for schema-congruent information and, thus, to collect evidence that supports suspicions about BI. This priming effect can generate an accelerating loop whereby suspicions lead to a confirmatory perceptual bias, which in turn generates evidence for the initial suspicion, and so on. These factors combine to suggest that some people are more "perceptually ready" than others to detect BI issues. If it is assumed that no managers are perfect and all managers have some degree of misalignment between word and deed, some people will notice and care about this misalignment more than others.

We argue that this form of perceptual readiness may be stronger among Black employees than among non-Black employees. In one study by Crocker, Luhtanen, Broadnax, and Blaine (1999), Black students were found to be very likely to believe statements that the U.S. government did things such as plant the AIDS virus in the

Black community to hurt Black people or keep Black people homeless so they would be less powerful-even though these actions would be inconsistent with government espousal of minority rights and equal opportunity. White students were very unlikely to accept such beliefs. This difference between Whites and Blacks was massive, with White student scores for agreement with the above statements at around 1.5 on a 5point scale and Black student scores at around 4.0. One should not be surprised to find these types of heightened suspicions among Blacks. Ongoing experiences of Black people in the United States make the BI schema highly available and relevant.

Looking back historically, there are instances in which the U.S. government was indeed found to be dishonest in its dealings with Blacks. One of the most famous cases occurred from 1932 to 1972, when 201 Black sharecroppers in Alabama were denied treatments for syphilis as part of the Tuskegee Syphilis Study (Jones, 1993). Physicians 
of the U.S. health service led these men to believe that they were being treated, but actually they were kept away from any treatment as a means of learning what happens when the disease goes untreated. The study was stopped only when it was exposed by the New York Times in 1972. With such a radical misalignment between words (promised treatments) and deeds (no treatment), Black Americans' expectations of low $\mathrm{BI}$ by those in power are very justifiable. Moreover, this historic case is well known and often talked about in the Black community (Gamble, 1997; Syphilis Study Legacy Committee, 1996).

Blacks also have good reason to doubt the word-deed alignment of business leaders in the United States. While Xerox Corporation was sponsoring public television shows about Black history and strongly supporting Black causes in the early 1970s, some Xerox managers were assigning Black salesmen only to clients who bought small machines with lower commission rates (Friedman \& Deinard, 1991). While Texaco widely displayed their affirmative action and diversity goals, as did all U.S. companies in the early 1990s, several of its top executives were describing Black employees as "black jelly beans" and talking about destroying documents to prevent successful discrimination suits (Eichenwald, 1996). More broadly, discrimination continues (Cancio et al., 1996) despite public commitments to equal opportunity. On a more personal level, Black employees' ability to accept their managers' statements at face value may be inhibited by the fact that White managers tend not to recognize or perceive race as an issue when Black employees almost universally experience it as such (Thomas, 1989).

In private business dealings, as well, similar cases have been uncovered. Car salespeople have been shown to systematically charge Blacks more than Whites for the same car (Ayres, 1991). According to Ayres, when salespeople tell Blacks that their "bottom line" is a certain amount, they often turn around and provide Whites with still lower prices for cars. More recently, lawyers have discovered that car salespeople systematically charge Blacks higher interest rates for car loans, even after controlling for customer credit risk (Henriques, 2001). In terms of both famous cases and personal experiences, Blacks have often been told one thing while actual behavior was different. And it is not only Whites who present such word-deed misalignments. In the study of car prices, Ayres (1991) found that the same pattern of charging Blacks more for cars was found among Black salespeople, not just White salespeople.

These types of experiences can create widespread cynicism and suspicion. Among Blacks, it is easy to believe in conspiracies by the U.S. government (Crocker et al., 1999). There is suspicion about health care providers (Jones, 1993), police and courts (Anderson, 1996) and, more broadly, those in positions of power and authority (Triandes, Feldman, Weldon, \& Harvey, 1976). Carrying this perspective to the work world, it is not farfetched to believe that the boss who says nice things about you in public may take actions to hold back your career in private. These factors should create, among Blacks, a higher perceptual readiness to notice gaps in word-action alignment and hence to question BI. 
Having heard about lies and inconsistencies among public figures, corporate executives, and even local salespeople, Blacks are likely to be highly vigilant about BI, expecting that it is at least feasible that a given manager might speak one way and act in another. Thus, BI or, conversely, hypocrisy may be a schema that is readily available and frequently applied by Blacks. With that starting point, Black employees are more likely to notice misalignments between words and deeds among managers, because people tend to look for evidence that confirms their preexisting expectations (Fiske \& Taylor, 1991). As a result, any initial suspicions about a lack of BI are likely to develop a kind of inertia (Simons, 2002). The perceptual priming effect (Bruner, 1957) means that constructs such as BI, once applied to reality, will increase the likelihood of further applications of the construct. This phenomenon can be seen in psychological contracts (mistreated employees are likely to watch more carefully than are others for further breaches of psychological contracts; Rousseau, 1995) and mistrust (employees who experience unmet promises are more likely to detect further unmet promises; Robinson, 1996). Within the Black community, we argue, the schema of word-deed inconsistency is highly available, is likely to result in observations that confirm preexisting suspicions, and is self-reinforcing.

Black employees may also be more sensitive to their managers' BI because they depend more on their managers than do non-Black employees. For all employees, formally defined relationships, such as those one has with a manager or boss, are complemented by many additional ties that are less formal. These ties develop through social contacts and are based on common interests and interpersonal attraction. Although not formal, they are nonetheless critical for employee success, because they provide help with socialization (Van Maanen \& Schein, 1979), information about people and activities in the organization (Granovetter, 1973), and social support (Fisher, 1985; Heimer, 1992). Black employees may not have as complete a network of informal ties as do White employees (Friedman, 1996; Ibarra, 1993). If one combines the fact that Blacks are usually in the minority within organizations, especially in managerial ranks, and the fact that people tend to form ties more easily with those who are socially similar (McPherson \& Smith-Lovin, 1987), it is less easy for Blacks to develop as extended a social network at work as do Whites. As a result, Blacks may be more likely than Whites to depend on formal ties such as that with a manager. Any potential indicators that a manager cannot be trusted, such as word-deed inconsistencies, are thus likely to be more threatening for Blacks than for Whites. Given the heightened vigilance suggested by these factors, coupled with the supposition that most managers are less than perfect in their word-deed alignment, we propose the following:

Hypothesis 1: Black employees will report lower levels of BI by their managers than will non-Black employees.

BI as a Mediator 
Simons (2002) argued that the perception of one's manager's BI is a driver of many workplace attitudes. Employee perceptions of patterns of unfulfilled promises, inconsistent messages, and hypocrisy on the part of managers-their BI-are likely to have profound attitudinal and behavioral consequences. If one believes that one's boss has a pattern of being less than fully forthright, one is less likely to trust that boss. This assertion applies whether one defines trust as a construct that includes ascriptions of honesty (e.g., Cummings \& Bromiley, 1996) or simply as willingness to accept vulnerability (Mayer et al., 1995). If one defines trust as including perceptions of honesty, then the link is almost tautological. If one defines trust as willingness to accept vulnerability, then a perception of broken promises or misrepresented values (espousals that are not enacted) would lead an observer to conclude that the target is at best unreliable and at worst malevolent-both conclusions would reduce rational willingness to accept vulnerability.

Bies (2001) described deception-which he defined as non-correspondence between words and action-as a "profanity" that triggers outrage, mistrust, and a sense of interactional injustice. Bies's earlier work with colleagues (Bies \& Moag, 1986; Bies \& Tripp, 1996) highlighted the role of unfulfilled promises in giving rise to perceptions of injustice. More recently, Bies (2005) drew on Colquitt, Conlon, Wesson, and Ng's (2001) meta-analysis to assert that the interactional justice construct should be further broken down into interpersonal justice and informational justice. On the basis of these arguments, BI perceptions should influence employee perceptions of interpersonal justice.

Perception of a pattern of inconsistent messages from one's boss-one message conveyed by words and another conveyed by actions-would likely cause one to be dissatisfied with that boss and may well spill over to global dissatisfaction. Support for this assertion may be drawn from studies of role conflict and role ambiguity. Worddeed misalignment sends mixed messages that are likely to give rise to tension between understood aspects of the job (role conflict) and confusion about job expectations (role ambiguity). For example, if a manager says an employee should do one thing but rewards different behaviors, then the focal employee will be receiving conflicting expectations about how to behave (role conflict) and/or confused or uncertain expectations about how to behave (role ambiguity). Jackson and Schuler's (1985) meta-analysis found that role conflict and role ambiguity are correlated with global job satisfaction ( $r s=-.31$ and -.30 , respectively). Managers' word-deed misalignment can readily be conceived as communicative inconsistency, which is likely to affect subordinates' role conflict and role ambiguity. Thus, BI perceptions are likely to affect trust in management and global satisfaction.

BI can also affect organizational commitment. It is hard to imagine an employee feeling affective commitment to a company when the most salient representative of that company-his or her manager-demonstrates a pattern of broken promises and misrepresented values. Meyer and Allen (1997) and Folger and Konovsky (1989) have noted the well-established link between fairness perceptions and organizational commitment. Role ambiguity and role conflict, to which BI is a logical antecedent, have 
been shown repeatedly to strongly affect organizational commitment (Mathieu \& Zajac, 1990). Wanous, Poland, Premack, and Davis (1992) found in a meta-analysis that, on average, unmet expectations correlated with organizational commitment at $r=-.39$. In this context, we assert that managers' low BI would likely be associated with employees' unmet expectations. Whereas the BI construct per se is new to empirical study, these studies of related constructs suggest an association between BI and commitment.

Finally, we would also expect BI to affect turnover intentions. Role ambiguity and role conflict, likely correlates of BI, have been shown to affect employee turnover intentions (Kemery, Bedeian, Mossholder, \& Touliatos, 1985). Shapiro and Kirkman (1999) found, in a study of 500 employees in self-managing work teams, that anticipatory injustice predicted both organizational commitment and turnover intentions. The attitudinal consequences suggested by all of the above argumentsjustice, satisfaction, and commitment-have also been empirically demonstrated to drive employee turnover intentions (Cohen, 1993; Cotton \& Tuttle, 1986; Tett \& Meyer, 1993). It seems reasonable to assert that employees who describe their managers as displaying low BI will be readier to seek a new employer than will employees who describe their managers in more positive terms.

In sum, though few published studies have explicitly examined the attitudinal and behavioral consequences of BI perceptions (an exception being Dineen et al.'s, 2006, study), ample indirect evidence suggests profound effects. Specifically, we infer that BI is likely to affect employees' trust in management, their interpersonal justice perceptions, their global satisfaction levels, their commitment levels, and their intent to stay with the company.

Hypothesis 2a: Lower levels of reported BI will be associated with lower levels of trust in management, interpersonal justice perceptions, global satisfaction, affective commitment, and intent to stay.

As a result of Hypothesis 1, which states that Black employees will report lower levels of $\mathrm{BI}$, we predict the following:

Hypothesis 2b: Black employees will report lower levels of trust in management, interpersonal justice perceptions, global satisfaction, affective commitment, and intent to stay.

Hypothesis 2c: The relationship between Black employee race and trust in management, interpersonal justice perceptions, global satisfaction, affective commitment, and intent to stay will be mediated by BI perceptions. 
Similarity-attraction theory has shown that people tend to be attracted to those who are similar to themselves (Berscheid \& Walster, 1969; Byrne, 1971). Similarity can be attitudinal (Harrison, 1976) or demographic (Lincoln \& Miller, 1979) and predicts social dynamics such as openness of communication (Zenger \& Lawrence, 1989) and how people evaluate others' work performance (Kraiger \& Ford, 1985; Landy \& Farr, 1980). Social identity theory (Tajfel \& Turner, 1986) proposes a second mechanism with similar consequence. This theory argues that the need for self-esteem causes people to (a) identify themselves as group members, such as members of a family, organization, or demographic category such as race or gender; and (b) see their groups and other members of those groups as especially good (Brockner, 1988). Early experiments in social identity theory showed that, when shown a fuzzy picture of beans in a jar that had supposedly been collected by one group or another, people provided higher estimates when they thought that members of their own group did the collecting (Sherif, Harvey, White, Hood, \& Sherif, 1961). People are predisposed to view members of their own group in a more positive light than those from another group.

The study of organizational demography has shifted in recent years away from the main effects of race and toward a focus on differences in demographic characteristics (e.g., race) among team members (O'Reilly, Caldwell, \& Barnett, 1989; Riordan \& Shore, 1997) and between managers and subordinates (Tsui \& O'Reilly, 1989; Vecchio \& Bullis, 2001). The argument has been that when employees work with similar others in teams, they are more likely to be committed to the organization and show up to work (Tsui, Egan, \& O'Reilly, 1992) and less likely to want to leave (Jackson et al., 1991). These scholars have proposed that when employees work with a boss who is more like them demographically, they are more likely to be satisfied with the supervisor (Vecchio \& Bullis, 2001), to report higher levels of procedural justice and job satisfaction (Wesolowski \& Mossholder, 1997), and to exhibit more citizenship behaviors (Perry, Kulik, \& Zhou, 1999). On the basis of this literature, we might expect that Black employees would give Black managers the benefit of the doubt and might therefore be less likely to notice word-deed misalignments. Conversely, racial differences between employee and manager might result in depressed scores for BI and other perceptions.

This idea is supported by the results of a vignette study by Davidson and Friedman (1998), who found that Black employees were more likely to accept an explanation for managerial bad behavior that came from a hypothetical Black manager than from a hypothetical White manager. Vecchio and Bullis (2001) found that racial similarity was associated with satisfaction with supervisor and continued membership in the army. Wesolowski and Mossholder (1997) found that racial similarity between subordinate and supervisor predicted perceptions of procedural justice and job satisfaction.

We would expect, then, that Blacks might be more supportive of Black managers, less suspicious of them, and more willing to give them the benefit of the 
doubt in ambiguous situations. Conversely, Blacks might be especially cautious in their acceptance of statements by non-Black managers. As Rousseau and Schalk (2000) argued, "consistent behavior is more important for trustworthiness when people are from different groups than when they are from the same group" (p. 301). For these reasons, we expected that Black employees would have more positive perceptions of their manager's BI when the manager was also Black. Thus, we hypothesize the following:

Hypothesis 3: Black employees' perceptions of their managers' BI will be less positive when they are managed by non-Black managers. This effect will result in a statistical interaction between employee race and manager race, such that Black employees' BI perceptions will be relatively low when they describe non-Black managers, but not when they describe Black managers.

\section{The Trickle-Down Effect}

Employee reports of managers' BI may be understood as containing information about the managers' actual word-action alignment and about the individual employee's bias in perceiving and reporting the word-action alignment. Such reports combine information about the target and the observer. Racial differences in reported BI scores may thus be the result of managers' different conduct to Black employees or of different perceptual processes in the eyes of Black employees. It is of practical import to distinguish the extent to which managers are actually more hypocritical (show lower BI) toward Black employees and the extent to which Black employees are predisposed to seeing their managers as such. However, the lack of objective data on BI-and the infeasibility of such data-make the distinction difficult.

In an effort to more clearly distinguish the extent to which racial differences in BI reports are driven by perceptual processes, as opposed to actual differential treatment, we sought a mechanism that could be expected to affect managers' actual word-action alignment. If the impact of that mechanism were enhanced for Black observers, it would, by the rule of parsimony, provide evidence in support of a perceptual sensitivity phenomenon. The trickle-down effect (Masterson, 2001) suggests one such mechanism: Middle managers are likely to take upper level managers as role models and so may behaviorally emulate the level of word- deed alignment they see in their organizational superiors. In this fashion, BI may be expected to trickle down from higher levels in the organization to lower levels. The existence of such a trickledown effect can be readily inferred from Bandura's (1977) social learning theory, which examines the roles of modeling or imitation in learning. Bandura found, on the basis of a substantial body of social psychological experimentation, that modeling is especially likely to occur when the object commands attention; when the object has high perceived levels of status, competence, and power; when the object has control over critical rewards; and when behavioral consequences of the emulated action are unclear or ambiguous. In the workplace, these conditions apply vividly to supervisors or middle 
managers' modeling of their superiors and upper level management, and the social learning theory of modeling has been substantially supported in this context (Weiss, 1977).

There is some evidence of a trickle-down dynamic in the study of justice. Masterson (2001) studied 187 classrooms and found that instructors' justice perceptions regarding treatment by administration drove their prosocial behaviors, which in turn affected students' perceptions of the instructors' fairness in a mechanism she termed trickle down. Masterson interpreted her instructor-student results as reflective of service providers and customers. However, the instructor-student relationship may also be considered as very similar to the manager-employee relationship. In fact, the power differential between instructor and student more closely resembles the manageremployee relationship than the service-provider-customer relationship. The trickle down that Masterson proposed is conceptually similar to our own. However, the mechanism she proposes differs in that justice and fairness are different constructs from BI and in that the principal-teacher-student relationship differs from the upper manager-middle-manager-line-employee relationship.

We would expect a trickle down of BI among upper and middle managers and employees regardless of employee race, because it would in theory affect the middle managers' actual level of word-deed alignment. However, because we expected that Black employees would be more sensitive to BI, any increment of difference in a manager's behavior that comes from that manager's perception of upper management BI should be noticed more readily by Black subordinates than by non-Black subordinates. If Black-non-Black differences in BI perception result from greater perceptual sensitivity on the part of Black employees, then we would expect that any trickle-down effect will be stronger when the observer is Black. If the differences are driven by different behavior exhibited to Black employees, we would not make the same prediction.

Hypothesis 4a: Employees' perceptions of their managers' BI will be positively associated with those managers' perceptions of upper management's BI.

Hypothesis 4b: Black employees' perceptions of their managers' BI will be associated more strongly with their managers' perceptions of upper level management's BI than will non-Black employees' perceptions of their managers' BI. This heightened association will lead to a significant interaction between employee race and managers' ratings of upper level managers.

\section{Method}


Data were collected in 1999 from 111 different hotel properties in Canada and the United States run by a single large hotel management company. Surveys were administered by the employee services department and offered to all 10,286 employees during company time at each of the hotel locations. Participation was encouraged in part by a raffle for one of several sweatshirts and other trinkets. There was a $66 \%$ response rate $(6,792$ completed surveys returned); $74 \%$ of the surveys were administered in English, and 24\% were administered in Spanish, with the balance of the questionnaires administered in Chinese, Creole, French, and Vietnamese. The questionnaires were translated into each of these languages following standard translation/back-translation procedures and were individually pilot tested. In addition, an attempt was made to query illiterate employees by offering a "read-aloud" table at all survey administrations, in which an employee services manager from another property talked illiterate employees through the survey. Approximately $7 \%$ of the employees availed themselves of this opportunity.

We did not, however, use the entire sample for this study. Several of our hypotheses focus on characteristics of the manager, including the race of the manager and the manager's assessment of the BI of his or her superior (called upper level manager). In cases in which there were multiple managers within a given department, we could not clearly assess these characteristics for a particular respondent's manager. Therefore, we excluded those departments, leaving only those with one identifiable manager. Our final sample included 1,944 line employees working under 449 managers at 107 different hotel properties.

Among the 1,944 employees, the racial/ethnic distribution was $19.1 \%$ African American, 7.3\% Asian or Pacific Islander, 39.2\% Caucasian, 24.6\% Hispanic, 1.4\% Native American Indian, and $8.4 \%$ other. Median age was $31-35$ years, median tenure at the hotel was 1-2 years, and median education was high school. Men made up $43.6 \%$ of the employee participant pool; $56.4 \%$ of the employee participants were women. Among the 449 managers, the ethnic distribution was 13.9\% African American, $3.6 \%$ Asian or Pacific Islander, 65.8\% Caucasian, 9.6\% Hispanic, 1.2\% Native American Indian, and $6.0 \%$ other. Median age of the managers was 35-40 years, median tenure at current hotel was $1-2$ years, and median education was some college; $48.6 \%$ of the managers were men, and $51.4 \%$ were women.

\section{Measurements}

All attitudinal constructs were measured with 5-point Likerttype scales ranging from 5 (strongly agree) to 1 (strongly disagree). BI was measured using an eight-item scale. Sample items are "My manager practices what he preaches" and "My manager delivers on promises." Trust in the manager was measured using three items derived from Mayer et al.'s (1995) conceptualization of trust as willingness to accept 
vulnerability to another party. Sample questions in our scale include "I would not mind putting my well-being in my manager's hands" and "I would feel good about letting my manager make decisions that seriously affect my life." (See the Appendix for the complete behavioral integrity and trust scales.) Commitment was measured using a sixitem scale from Mowday, Steers, and Porter (1979). Sample scale items are "I am proud to tell others that I am part of this hotel," "I care about the fate of this hotel," and "This hotel inspires me to do my best." Interpersonal justice was measured using a simplified version of the Niehoff and Moorman (1993) scale that was reported in Simons and Roberson's (2003) study. Scale items are similar to those proposed by Colquitt (2001); Colquitt's items were not available at the time of data collection. A sample item for interpersonal justice is "When hotel management staff make decisions about my job, they treat me with kindness." Employee intent to remain was measured using a scale from Robinson (1996). This four-item scale asked employees to respond to three Likert-type questions about how long they intended to remain with the employer ( $5=$ more than 8 years, $1=0-1$ year), the extent to which they would prefer to work for a different employer $(5=$ a great deal, $1=$ not at all), the extent to which they have thought about changing companies ( $5=$ a great deal, $1=$ not at all), and one binary question ("If you had your way, would you be working for this employer three years from now?"). To address heterogeneity of variance across items, we followed Robinson's procedure of standardizing item responses prior to developing scale scores. All of the above measures demonstrated reliability equal to or greater than $\alpha=.75$. Table 2 reports the descriptive statistics, Cronbach's alphas, and intercorrelations for the variables.

To ensure that each of these scales measures distinct concepts, we completed a confirmatory factor analysis. To mitigate against common-method variance, we used a method developed by Williams and Anderson (1994) that entails cross-loading all scale items on a conceptually unrelated scale from the same survey; in this case, a willingness to say negative things about people at work and the organization. This measure was included in the regression analyses (reported below), also to mitigate against common method variance. The six-factor model (BI, Satisfaction, Trust, Commitment, Interpersonal Justice, and Intent to Stay) had a comparative fit index of .96 , a standardized root-mean residual of .03, and a root-mean-square error of approximation of .05, which shows overall good fit according to the criteria laid out by Hu and Bentler (1999). We did additional analyses to test whether BI and trust in management are separate, given that they had the highest interscale correlation (.84). Merging the two constructs resulted in a significantly worse model fit, $\Delta x^{2}(5, N=$ $743)=2,191.72, p<.001$.. Thus, a six-factor model fits the data best. Detailed results of these analyses are available from Tony Simons.

\section{Results}


Hypothesis 1 proposed that Black employees would report lower levels of manager BI than would non-Black employees. To test this hypothesis, we regressed employees' perceptions of their direct manager's BI on a dummy variable for Black employee, as well as controls for age, tenure at hotel, education, and gender. Results are shown in Table 3 (Model 1) and indicate, as expected, that Black employees reported lower managerial BI perceptions than did non-Black employees.

To test Hypotheses $2 \mathrm{a}, 2 \mathrm{~b}$, and $2 \mathrm{c}$, we followed the method established by Baron and Kenny (1986). In each case (see Table 3), we retained the same controls used in Model 1 , with the addition of the willingness to criticize variable, which was included to attenuate common method variance. First, we ran a series of models testing whether the dummy variable (Black) was a significant predictor of trust in manager (Model 2), interpersonal justice (Model 4), satisfaction (Model 6), organizational commitment (Model 8), and intent to stay with the company (Model 10), as specified in Hypothesis $2 \mathrm{~b}$. These analyses showed that Black employees in this sample did report significantly lower levels of these variables. We then added to each of these models our measure of BI (Models 3, 5, 7, 9, and 11). In all cases, BI had a significant impact on the dependent variables (as specified in Hypothesis $2 a$ ) and reduced the coefficient for race to nonsignificance, which is consistent with Hypothesis 2c, that the effect of race on these dependent variables is fully mediated by BI.

Given the cross-sectional nature of our data and the high intercorrelations among the measured attitudinal variables, one can reasonably question the order of mediation for these variables. Where the second and third links of the proposed chain $A$ $\rightarrow \mathrm{B} \rightarrow \mathrm{C}$ are highly intercorrelated, it remains feasible, given the Baron and Kenny (1986) analysis, that the true chain is $A \rightarrow C \rightarrow B$. For this reason, we tested credible rival causal chains. We reasoned that trust or interpersonal justice might be proposed as a more direct consequence of race, following arguments like those we laid out, and that these attitudes might in turn affect BI perceptions as well as the other attitudes examined. Trust fully mediated the impact of race on BI, interpersonal justice, and intent to stay but only partially mediated the links between race and commitment and between race and satisfaction. Interpersonal justice mediated the link between race and intent to stay and partially mediated the link between race and satisfaction but did not mediate the links between race and BI, race and trust, or race and commitment. We reasoned also that intent to stay might somehow be affected by race and that this intent might affect the other attitudes and perceptions through a cognitive dissonance mechanism. Intent to stay mediated the link between race and interpersonal justice but did not mediate any of the other attitudinal correlates of race. In contrast, the data were consistent with the notion that BI mediated the impact of race on all of the attitudes of interest. In sum, trust, interpersonal justice, and intent to stay did not appear to mediate as many of the attitudinal correlates of race as did BI.

To test Hypothesis 3, that Black employees would report more positive perceptions of their manager's BI if the manager was Black and less positive if the manager was not Black, we moved to hierarchical linear modeling (HLM). HLM offers a statistical technique to examine relationships involving an individual-level dependent 
variable and predictors at both the individual level and the group level (Bryk \&, Raudenbush, 1992; Hofmann, 1997). In our case, race of manager is a group-level characteristic, as all employees within a department share and describe the same manager. To test Hypothesis 3, we created an interaction term between Black employee (an individual-level variable) and Black manager (a group-level variable), keeping in the model the same demographic controls used previously. As shown in Table 4 (Model 3), the interaction term was significant and negative $(\beta=-.31, p<$ $.05)$. Contrary to the hypothesis, Black employees were more critical of the BI of Black managers than they were of the BI of non-Black managers (see Figure 1). The difference in non-Black employees' assessments of Black and non-Black managers is not significant.

To test Hypothesis 4a, that a manager's perceptions of his or her superior's BI is associated with how line employees view that manager's BI, we added to the HLM model at Level 2 a measure of the manager's perceptions of the BI of his own boss, an upper-level manager. This effect was significant (Model 4 of Table 4), indicating that perceptions of upper-level managers by middle managers do trickle down to front-line employees. Middle manager perceptions of their superiors are associated with line employee perceptions of those middle managers. To test Hypothesis $4 \mathrm{~b}$, that this trickle-down effect will occur more strongly for Black employees, we added to the HLM model an interaction between Black employee and the manager's perception of his upper-level manager's BI. This interaction term, shown in Model 5 of Table 4, was significant and positive, which is consistent with Hypothesis 4b. Figure 2 displays this interaction effect. Because the graph suggests that the main trickle-down effect found in Model 4 might be due to Black employees only, we split the sample and ran the analysis with Black and non-Black employees separately. In each case, manager perceptions of upper level managers' BI had a significant effect on employees' perceptions of their manager's BI $(p<.01)$. Dividing the non-Black employee sample even further, looking only at those with non-Black managers, the effect was still significant $(p<.01)$. These analyses show that the trickle-down effect is not limited to Black employees or to those with Black managers. Further, they show that the impact of the trickledown mechanism is enhanced for Black employees.

\section{Discussion}

The data and analyses presented here are consistent with our assertion that Black employees are more sensitive to managers' BI than are non-Black employees and that this difference may, in turn, give rise to multiple attitudinal and behavioral consequences. Black employees in our sample tended to ascribe lower BI to their managers, and this ascription appears to mediate impacts of employee race on trust in manager, interpersonal justice, global satisfaction, affective commitment, and intent to stay. 


\section{Practical Implications}

Thus, cross-race differences in sensitivity to BI are no small matter-basic aspects of the relationship between an employee, his or her manager, and the organization he or she works for appear to be affected by BI perceptions. For those organizations trying to retain and promote Black employees as part of a strategy to increase diversity (U.S. Department of Labor, 1992), alignment between words and deeds is critical because low BI ascriptions increase Black employees' turnover intentions. For those organizations trying to better manage diversity, an understanding of cross-group differences in reaction to managerial style is critical.

The practical implication of this finding is that, if managers expect that moderate levels of word-deed misalignment are acceptable because many employee groups seem to tolerate them, this expectation could create trouble when applied to Black employees, because their reaction appears to be appreciably different. Managers should not assume that the accepting responses they get from the larger, non-Black employee population (which may be who they talk with most of the time) necessarily represent the sentiments of Black employees in the organization.

Not only do the effects of BI appear to be broad-affecting trust in management, interpersonal justice, organizational commitment, satisfaction, and turnover intentionsthey also appear to be very deep. Our data are consistent with the notion that BI perceptions carry through layers of an organization, trickling down from upper levels of management through supervisors and down to the level of first-line employees. Because of this pattern, a single inconsistent executive can create far-reaching negative consequences in an organization. Lack of word-deed alignment is noticed by mid-level managers who, in turn, seem to act more inconsistent themselves. If middle managers believe that their superiors do not keep promises, for example, they are more likely to break promises themselves. 
Table 4

Multilevel Random Coefficient Models Predicting Behavioral Integrity (BI)

\begin{tabular}{|c|c|c|c|c|}
\hline Variable & $\begin{array}{c}\text { Parameter } \\
\text { estimate } \\
\text { (unstandardized) }\end{array}$ & $S E$ & $t$ ratio & $\begin{array}{c}p \text { value } \\
\text { (two-tailed) }\end{array}$ \\
\hline \multicolumn{5}{|l|}{ Model 1} \\
\hline \multicolumn{5}{|l|}{ Level 1 model (no predictor) } \\
\hline Intercept & 3.60 & .03 & 112.42 & .00 \\
\hline \multicolumn{5}{|l|}{ Model 2} \\
\hline \multicolumn{5}{|l|}{ Level 1 model } \\
\hline Intercept & 3.60 & .03 & 113.02 & .00 \\
\hline Age & .03 & .01 & 2.36 & .02 \\
\hline Tenure & -.07 & .02 & -4.59 & .00 \\
\hline Education & -.01 & .02 & -.70 & .48 \\
\hline Gender & -.06 & .05 & -1.32 & .19 \\
\hline Black & -.15 & .06 & -2.40 & .02 \\
\hline \multicolumn{5}{|l|}{ Model 3} \\
\hline \multicolumn{5}{|l|}{ Level 1 model } \\
\hline Intercept & 3.59 & .03 & 113.86 & .00 \\
\hline Age & .03 & .01 & 2.36 & .02 \\
\hline Tenure & -.07 & .02 & -4.67 & .00 \\
\hline Education & -.01 & .02 & -.74 & .46 \\
\hline Gender & -.06 & .05 & -1.28 & .20 \\
\hline Black & -.09 & .07 & -1.42 & .16 \\
\hline \multicolumn{5}{|l|}{ Level 2 model } \\
\hline Black manager & -.23 & .09 & -2.29 & .02 \\
\hline Black employee $\times$ Black manager & -.31 & .13 & -2.41 & .02 \\
\hline \multicolumn{5}{|l|}{ Model 4} \\
\hline \multicolumn{5}{|l|}{ Level 1 model } \\
\hline Intercept & 3.60 & .03 & 111.78 & .00 \\
\hline Age & .03 & .01 & 2.11 & .04 \\
\hline Tenure & -.08 & .02 & -4.83 & .00 \\
\hline Education & -.02 & .02 & -1.51 & .13 \\
\hline Gender & -.06 & .05 & -1.17 & .24 \\
\hline Black & -.13 & .06 & -2.15 & .03 \\
\hline \multicolumn{5}{|l|}{ Level 2 model } \\
\hline Manager report of upper managers' BI & .14 & .03 & 4.03 & .00 \\
\hline \multicolumn{5}{|l|}{ Model 5} \\
\hline \multicolumn{5}{|l|}{ Level 1 model } \\
\hline Intercept & 3.61 & .03 & 113.07 & .00 \\
\hline Age & .03 & .01 & 2.08 & .04 \\
\hline Tenure & -.08 & .02 & -4.87 & .00 \\
\hline Education & -.02 & .02 & -1.47 & .14 \\
\hline Gender & -.06 & .05 & -1.25 & .21 \\
\hline Black & -.07 & .06 & -1.18 & .24 \\
\hline \multicolumn{5}{|l|}{ Level 2 model } \\
\hline Black manager & -.19 & .10 & -1.71 & .07 \\
\hline Black employee $\times$ Black manager & -.30 & .12 & -2.38 & .02 \\
\hline Manager report of upper managers' BI & .12 & .03 & 3.79 & .00 \\
\hline Black employee $\times$ Manager report of upper managers' BI & .13 & .07 & 1.93 & .05 \\
\hline
\end{tabular}


shape whole cultures. Executives and middle managers are under a microscope as lower level managers look to them for cues as to what is acceptable behavior.

Organizations, therefore, cannot compromise in setting clear expectations for integrity among top managers.

\section{Contributions to a Theory of Reception Aesthetics in Organizations}

The impact of trickle-down dynamics on BI is stronger among Blacks than among non-Blacks. If trickle-down dynamics cause middle managers to modify their actual word-action alignment to a given extent (say, X), Black employees report a larger

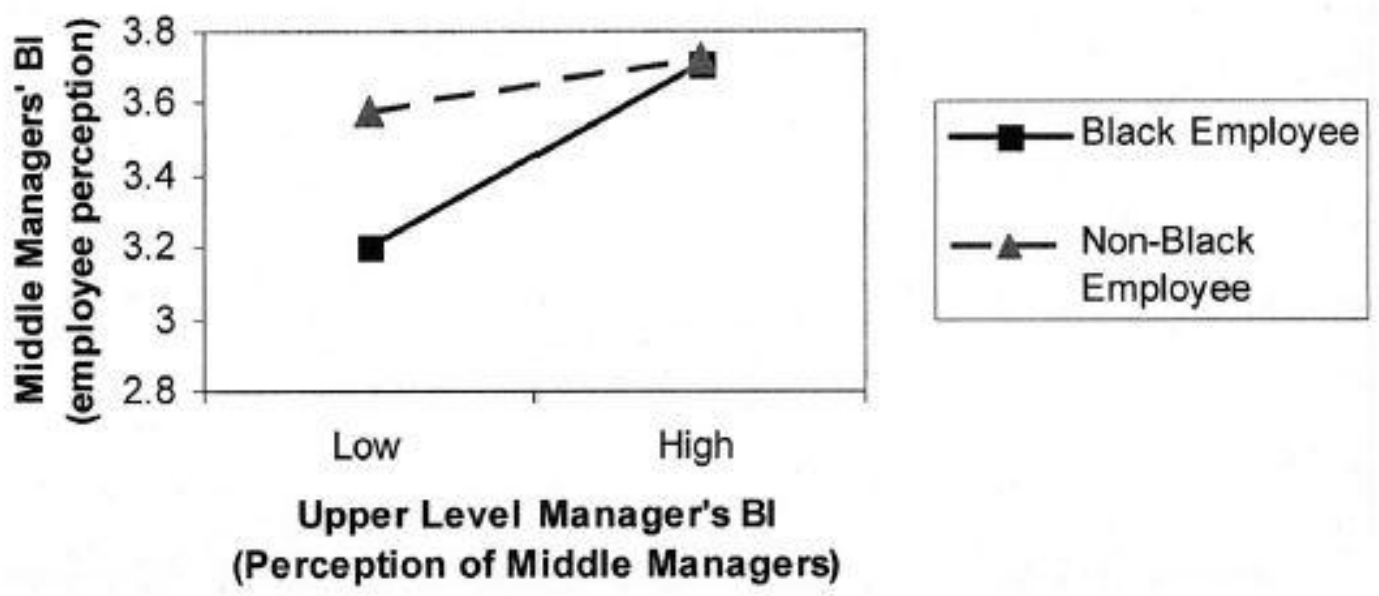

\section{Figure 2. Interaction of employee race and upper level manager behav- ioral integrity (BI).}

increment of difference (say, $X+1$ ). We believe that this differential impact is consistent with the argument that Black employees are more sensitive to inconsistencies and broken promises than are non- Black employees. In a sense, then, Black employees may provide management with the earliest warnings about lack of word-deed alignment, if companies were able to tap into those employees' perceptions of management.

On a theoretical level, this finding develops further the concept of a "reception aesthetics" within organizations, as suggested by Davidson and Friedman (1998); that is, because different groups respond to messages differently, those who communicate messages need to be aware of the unique patterns of interpretation within each group. Drawing on work in sociology of culture (Griswold, 1987), literature (Jauss, 1982), and social psychology (Fiske \& Taylor, 1991; Lord, Ross, \& Lepper, 1979; Sherif \& Hovland, 1961), Davidson and Friedman (1998) argued that the "social context of reception" shapes whether social accounts for unjust actions will succeed at making the receivers of those messages feel less angry about the way the victims were treated. One aspect 
of the social context of reception in the United States is race, and Davidson and Friedman found that the same accounts had differing impacts, depending on whether the recipient of the account was Black or White, the victim was Black or White, and the harm-doer was Black or White. Our findings in this study show a similar phenomenon in yet another context: Statements made that are inconsistent with actions are perceived differently by one group than they are by another. Once again, race permeates the context of social cognition.

\section{Contributions to Theories of Trust and Justice}

This study contributes to trust research in a few different ways. In it, we explored the impact of demographic differences on perceptions antecedent to trust development. Relatively few studies have explored the role of individual perceiver

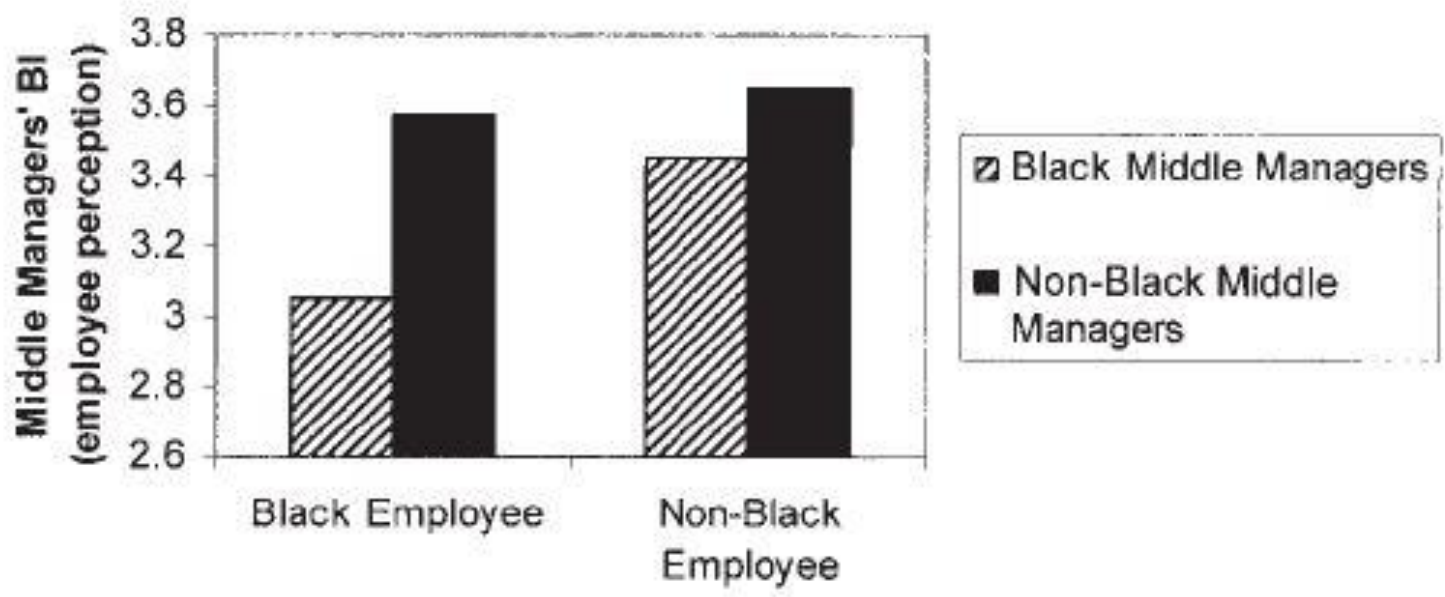

Figure 1. Interaction of employee race and middle manager race. $\mathrm{BI}=$ behavioral integrity.

differences in trust formation in a field setting (Dirks \& Ferrin, 2002). The study also adds to the growing evidence that trust in management has profound consequence. Given the importance of trust in management, this study suggests one of the mechanisms that needs to be addressed for effective management of a diverse workforce. BI is a strong predictor of trust in organizations, and it may be especially important for trust building in diverse workforces. Some employee groups, with reasons to be suspicious, can more easily lose trust in management if managers act in ways that are not consistent with their words.

This work also contributes to the literature on interactional justice, as it again begins to quantify how different demographic groups of perceivers process justice and injustice cues differently. It extends Davidson and Friedman's (1998) persistent injustice effect and applies it in particular to interpersonal justice. Perceptions of justice and injustice are central to effective diversity management (Huo \& Tyler, 2001), and the 
current study begins to shed light on very relevant demographic differences in the processing of justice and injustice cues. Bies (2005) called for additional research on interactional and interpersonal justice, and the current work responds to that call.

\section{Discrimination and Perceptions Considered}

Our results are consistent with the notion of heightened perceptual readiness on the part of Black employees. It may be argued, though, that the results emerged from differential treatment of Black and non-Black employees-Black employees may simply be subject to higher levels of bad behavior by their managers. We certainly do expect that Blacks might face higher levels of discrimination than do non-Blacks, but many of the actions taken and statements made by managers are necessarily public and visible to all subordinates. Widespread bad treatment of Black employees by a manager is likely to be noticed by many people and, thus, likely to result in lower perceived BI by both Black and non-Black subordinates- unless, as we argue, the Black employees are more likely to notice it. Also, the moderated trickle-down effects we found are not likely to be just the result of differential behavior toward Black and non-Black employees; there is no a priori reason to expect that manager perceptions of upper management's BI-which encompasses far more than just statements and actions about race-would differentially affect how managers act toward employees of different races. That said, it is very likely that both mechanisms are in some way operative in any given workplacethat some differential treatment actually occurs, and some is in the eye of the perceiver. Teasing out the relative contributions of each is a subject for future study. We consider our work to have opened the way for a more balanced examination of the experience of Black employees in the United States.

\section{Examining Unexpected In-Group Effects}

Hypothesis 3, which predicted that an in-group effect for race would cause Black employees to assess the BI of Black managers more favorably than White managers, was not supported. In fact, the results are consistent with an opposite hypothesis: Black employees appeared to rate the BI of Black managers more harshly than they rated the BI of White managers. On reflection, this result is consistent with a different body of literature. In their seminal article about relational demography, Tsui and O'Reilly (1989) found that supervisors' liking of subordinates was actually higher within dyads that were racially dissimilar, and role ambiguity and role conflict were lower. Moreover, Black subordinates reporting to White superiors had the lowest level of role ambiguity in their sample. More recently, one study conducted in China (Chan, 2002) expected better supervisor-subordinate relations when both were the same race but instead found that the worst relations occurred when the supervisor and the subordinate were both 
Chinese. This literature proposes that minority or low-power employees, and especially Blacks, may be more critical of in-group supervisors than out-group supervisors.

This pattern may be due to differences in expectations. Black employees may expect of Black managers especially good treatment, support for Black issues in the organization, or special recognition of their issues and concerns. We see some evidence for this in reports by Irons and Moore (1985), Davis and Watson (1982), and Dickens and Dickens (1982). These authors all cited pressures on Black managers to represent the Black community within their companies and provide support to other Black employees. This type of expectation has sometimes been institutionalized in the form of employee network groups (Friedman, 1996), in which more senior Black managers provide support to lower level Black employees. If expectations of Black managers are very high among Black employees, whatever these Black managers do is less likely to be deemed satisfactory among these employees. As Oliver and Burke (1999) have shown, satisfaction is heavily influenced by initial expectations. This mechanism may well apply to other underrepresented minorities and to women in the workplace.

\section{Caution About Misuse of Our Findings}

One might legitimately raise the concern that the results of this research could conceivably be used to support discriminatory policies in hiring or promotion, because they suggest that managing Black employees entails some special challenges. This work proposes that Black employees may be more likely to notice gaps between their managers' words and actions and, as a result, to develop negative work attitudes. We offer a few responses and cautions regarding any interpretation of this work as possible support for discrimination. First, discriminatory policies and practices are illegal and are, by most standards, considered to be unethical. Individuals differ dramatically from each other, and individual qualifications and performance, not group membership, are the only criteria for hiring and promotion that are both fair and economically sustainable. Further, the trickle-down analysis described here suggests that Black employees are not biased in their reporting; they are simply more sensitive to patterns of managerial consistency, either positive or negative. This distinction suggests that failing to hire a Black employee for fear he or she will perceive you as having low BI is like failing to hire a good doctor for fear he or she will give you bad news about your health. Other studies have suggested that BI affects all employees as well as company performance and that consistency is thus a critical managerial virtue. Further, Simons (2002) argued that managers will tend to have inaccurate perceptions of their own levels of BI because of the need to maintain a positive and consistent self-concept. The opinions of Black employees may thus represent a critical diagnostic resource that supports managers' development. The evidence presented here suggests that attending to BI concerns raised by Black employees is likely to improve company performance at the same time as it improves working conditions for all employee groups. 


\section{Limitations and Contributions}

Like all such studies, this one has methodological limitations that constrain the confidence with which results should be generalized. First, the data are cross-sectional, which limits the confidence with which causal direction may be asserted. However, most of our analyses are unaffected by this issue, as employee race can hardly be claimed to result from patterns of attitude or perception. However, it does weaken the confidence with which we assert the directionality of our mediation hypothesis. Second, the data for this study are drawn from a single industry, the hotel industry, which may have peculiar characteristics that drove our results. Similar studies should be undertaken in other industries and with other employee populations, including more educated populations.

From a conceptual standpoint, this work makes several contributions. First, it suggests a mechanism of perceptual readiness as a way to understand cross-race employee differences in attitudes and behaviors. Second, it suggests that the BI construct is of central importance in understanding such differences. Third, it highlights a tension between Black employees and Black managers that needs to be further explored and better understood. Fourth, it articulates and demonstrates a trickle-down phenomenon, from executives to managers to line employees. This general mechanism of trickle down is likely one of the key methods of transmission and affirmation of organizational cultures, values, and behavioral norms. The notion that culture change in organizations must happen from the top down is generally accepted by practitioners. The concept of trickle down, whereby managers at each level monitor and emulate the values enacted by their supervisors, may provide a way to think about and to study organizational culture and change with greater precision. As such, the operation and application of trickle down as a general phenomenon represents a potentially fertile avenue for further research.

From a practical perspective, the current work has serious implications for managers and executives grappling with the effective management of diversity. Whereas managerial word-deed misalignments can have detrimental effects for all employees, they can have especially detrimental effects for Black employees, who might be more likely to notice them and to process them as indicators of low BI. The consequence is that managers can more easily lose the confidence of their Black employees than that of other employees, which in turn may undermine those employees' sense of justice, commitment, and trust in their managers. These attitudes in turn affect both individual and organizational performance. BI perceptions have been shown to have significant importance for employees in general and for company performance (Simons \& McLean Parks, 2000), and they appear to be especially critical for Black employees. Given the likely inaccuracies of managers' self-perception regarding word-deed alignment (Simons, 2002), regular employee surveys are indicated as a management tool. 


\section{Appendix}

Scales Used

\section{Behavioral Integrity}

The following items were rated on a 5-point Likert scale ( $5=$ strongly agree, $4=$ agree, 3 = neither agree nor disagree, 2 = disagree, $1=$ strongly disagree):

There is a match between my manager's words and actions.

My manager delivers on promises.

My manager practices what he/she preaches.

My manager does what he/she says he/she will do.

My manager conducts himself/herself by the same values he/she talks about. My manager shows the same priorities that he/she describes.

When my manager promises something, I can be certain that it will happen. If my manager says he/she is going to do something, he/she will.

\section{Trust}

The following items were rated on a 5-point Likert scale ( $5=$ strongly agree, $4=$ agree, 3 = neither agree nor disagree, 2 = disagree, 1 = strongly disagree):

I would be willing to let my manager have complete control over my future in this company.

I would not mind putting my well-being in my manager's hands.

I would feel good about letting my manager make decisions that seriously affect my life. 


\section{References}

Anderson, C. D. (1996). Understanding the inequality problematic: From scholarly rhetoric to theoretical reconstruction. Gender and Society, 10, $729-746$.

Arce, C. H., Murguia, E., \& Frisbie, W. P. (1987). Phenotype and life changes among Chicanos. Hispanic Journal of Behavioral Sciences, 9, 19 -32.

Ayres, I. (1991). Fair driving: Gender and race discrimination in retail car negotiation. Harvard Law Review, 104, 817-872.

Bandura, A. (1977). Social learning theory. Englewood Cliffs, NJ: Prentice-Hall.

Baron, R., \& Kenny, D. (1986). The moderator-mediator variable distinction in psychological research. Journal of Personality and Social Psychology, 51, 11731182.

Barringer, H. R., Takeguchi, D. T., \& Xenos, P. (1990). Education, occupational prestige, and income of Asian Americans. Sociology of Education, 63, 27- 43.

Berscheid, E., \& Walster, E. (1969). Interpersonal attraction. Reading, MA: AddisonWesley.

Bies, R. J. (2001). Interactional (in)justice: The sacred and the profane. In J. Greenberg \& R. S. Cropanzano (Eds.), Advances in organizational justice (pp. 89 -118). Stanford, CA: Stanford University Press.

Bies, R. J. (2005). Are procedural justice and interactional justice conceptually distinct? In J. Greenberg \& J. Colquitt (Eds.), Handbook of organizational justice (pp. 85112). Mahwah, NJ: Erlbaum.

Bies, R. J., \& Moag, J. F. (1986). Interactional justice: Communication criteria of fairness. In R. J. Lewicki, B. H. Sheppard, \& M. H. Bazerman (Eds.), Research on negotiations in organizations (Vol. 1, pp. 43-55). Greenwich, CT: JAI Press.

Bies, R. J., \& Tripp, T. M. (1996). Beyond distrust: "Getting even" and the need for revenge. In R. M. Kramer \& T. R. Tyler (Eds.), Trust in organizations: Frontiers of theory and research (pp. $246-260$ ). Thou- sand Oaks, CA: Sage.

Brockner, J. (1988). Self-esteem at work: Research, theory, and practice. Lexington, MA: D.C. Heath.

Bruner, J. S. (1957). Going beyond the information given. In J. S. Bruner, E. Brunswik, L. Festinger, F. Heider, K. F. Muenzinger, E. E. Osgood, \& D. Rapaport (Eds.), Contemporary approaches to cognition (pp. 41-69). Cambridge, MA: Harvard University Press.

Brunsson, N. (1989). The organization of hypocrisy: Talk, decisions, and actions in organizations. New York: Wiley.

Bryk, A. S., \& Raudenbush, S. W. (1992). Hierarchical linear models. Newbury Park, CA: Sage.

Byrne, D. E. (1971). The attraction paradigm. New York: Academic Press.

Cancio, A. S., Evans, T. D., \& Maume, D. J. (1996). Reconsidering the declining significance of race: Racial differences in early career wages. American Sociological Review, 61, 541-556. 
Chan, K. A. (2002, August). Relational demography, communication, and supervisor satisfaction. Paper presented at the annual meeting of the Academy of Management, Denver, CO.

Cohen, A. (1993). Organizational commitment and turnover: A meta- analysis. Academy of Management Journal, 36, 1140-1157.

Colquitt, J. A. (2001). On the dimensionality of organizational justice: A construct validation of a measure. Journal of Applied Psychology, 86, $386-400$.

Colquitt, J. A., Conlon, D. E., Wesson, M. J., Porter, C., \& Ng, K. Y. (2001). Justice at the millennium: A meta-analytic review of 25 years of organizational justice research. Journal of Applied Psychology, 86, 425- 445.

Cotton, J. L., \& Tuttle, J. M. (1986). Employee turnover: A meta-analysis and review with implications for research. Academy of Management Review, 11, 55-70.

Crocker, J., Luhtanen, R., Broadnax, S., \& Blaine, B. E. (1999). Belief in U.S. government conspiracies against Blacks among Black and White college students: Powerlessness or system blame? Personality and Social Psychology Bulletin, 25, 941-953.

Cummings, L. L., \& Bromiley, P. (1996). The organizational trust inventory (OTI): Development and validation. In R. M. Kramer \& T. R. Tyler (Eds.), Trust in organizations: Frontiers of theory and research (pp. 302-330). Thousand Oaks, CA: Sage.

Davidson, M., \& Friedman, R. A. (1998). When excuses don't work: The persistent injustice effect among black managers. Administrative Science Quarterly, 43, 154 $-183$.

Davis, G., \& Watson, G. (1982). Into the mainstream: Black life in corporate America. Garden City, NY: Anchor Books.

Demaris, A., \& Yang, R. X. (1994). Race, alienation, and interpersonal mistrust. Sociological Spectrum, 14, 327-349.

Dickens, F., Jr., \& Dickens, J. B. (1982). The Black manager. New York: Amacom Books.

Dineen, B. R., Lewicki, R. J., \& Tomlinson, E. (2006). Supervisory guidance and behavioral integrity: Relationships with employee citizen- ship and deviant behavior. Journal of Applied Psychology, 91, 622- 635.

Dirks, K. T., \& Ferrin, D. L. (2002). Trust in leadership: Meta-analytic findings and implications for research and practice. Journal of Applied Psychology, 87, 611628.

Eichenwald, K. (1996, November 4). Texaco executives, on tape, discussed impeding a bias suit. New York Times, p. A1.

Fisher, C. D. (1985). Social support and adjustment to work: A longitudinal study. Journal of Management, 11, 43-57.

Fiske, S. T., \& Taylor, S. E. (1991). Social cognition. New York: McGraw- Hill.

Folger, R., \& Konovsky, M. A. (1989). Effects of procedural and distributive justice on reactions to pay raise decisions. Academy of Management Journal, 32, 115-130.

Foy, N. (1985). Ambivalence, hypocrisy, and cynicism: Aids to organizational change. New Management, 2, $49-53$. 
Friedman, R. A. (1996). Defining the scope and logic of minority and female network groups: Can separation enhance integration? In G. Ferris (Ed.), Research in personnel and human resources management (pp. 307-349). London: JAI Press.

Friedman, R. A., \& Craig, K. (2004). Predicting joining and activism in minority employee network groups. Industrial Relations, 43, 793- 816.

Friedman, R. A., \& Deinard, C. (1991). Black caucus groups at Xerox (Harvard Business Case No. 5- 491-109). Boston: Harvard Business School Press.

Gamble, V. (1997). Under the shadow of Tuskegee: African Americans and health care. American Journal of Public Health, 87, 1773-1778.

Granovetter, M. S. (1973). The strength of weak ties. American Journal of Sociology, $78,1360-1380$.

Greenberg, J. (1990). Employee theft as a reaction to underpayment inequity: The hidden cost of pay cuts. Journal of Applied Psychology, 75, 561-568.

Griswold, W. A. (1987). The fabrication of meaning: Literary interpretation in the United States, Great Britain, and the West Indies. American Journal of Sociology, 92, 1077-1117.

Hacker, A. (1992). Two nations: Black and White, separate, hostile, and unequal. New York: Scribner.

Hackman, J. R., \& Oldham, G. R. (1975). Development of the job diagnostic survey. Journal of Applied Psychology, 60, $159-170$.

Harrison, A. A. (1976). Individuals and groups: Understanding social behavior. Belmont, CA: Wadsworth.

Heimer, C. (1992). Doing your job and helping your friends: Universalistic norms about obligations to particular others in networks. In N. Nohria \& R. G. Eccles (Eds.), Networks and organizations: Structure, form, and action (pp. 143-164). Boston: Harvard Business School Press.

Henriques, D. B. (2001, July 4). Review of Nissan car loans finds that Blacks pay more. New York Times, p. A1.

Hirschman, C., \& Wong, M. (1986). The extraordinary educational attainment of Asian Americans: A search for historical evidence and explanations. Social Forces, 65, $1-27$.

Hofmann, D. A. (1997). An overview of the logic and rationale of hierarchical linear models. Journal of Management, 23, 723-744.

Hsia, J. (1988). Asian Americans in higher education and at work. Hills- dale, NJ: Erlbaum.

Hu, L.-t., \& Bentler, P. M. (1999). Cutoff criteria for fit indices in covariance structure analysis: Conventional criteria versus new alternatives. Structural Equation Modeling, 6, 1-55.

Huo, Y. J., \& Tyler, T. R. (2001). Ethnic diversity and the viability of organizations: The role of procedural justice and bridging differences. In J. Greenberg \& R. S. Cropanzano (Eds.), Advances in organizational justice (pp. 213-244). Stanford, CA: Stanford University Press.

Ibarra, H. (1993). Personal networks of women and minorities in management: A conceptual framework. Academy of Management Review, 18, 56 - 87. 
Irons, E. D., \& Moore, G. W. (1985). Black managers: The case of the banking industry. New York: Praeger.

Jackson, S. E., Brett, J. F., Sessa, V. I., Cooper, D. M., Julin, J. A., \& Peyronnin, K. (1991). Some differences make a difference: Individual dissimilarity and group heterogeneity as correlates of recruitment, pro- motions, and turnover. Journal of Applied Psychology, 76, 675- 689.

Jackson, S. E., \& Schuler, R. S. (1985). A meta-analysis and conceptual critique of research on role ambiguity and role conflict in work settings. Organizational Behavior and Human Decision Processes, 36, 16 -78.

Jauss, H. R. (1982). Toward an aesthetic of reception. Minneapolis: University of Minnesota Press.

Jones, J. H. (1993). Bad blood: The Tuskegee syphilis experiment. New York: Free Press.

Kemery, E. R., Bedeian, A. G., Mossholder, K. W., \& Touliatos, J. (1985). Outcomes of role stress: A multisample constructive replication. Academy of Management Journal, 28, 363-375.

Kouzes, J. M., \& Posner, B. Z. (1993). Credibility: How leaders gain and lose it, why people demand it. San Francisco: Jossey-Bass.

Kraiger, K., \& Ford, J. K. (1985). A meta-analysis of ratee race effects in performance ratings. Journal of Applied Psychology, 70, 56-65.

Kramer, R. M. (1996). Divergent realities and convergent disappointments in the hierarchic relation: Trust and the intuitive auditor at work. In R. M. Kramer \& T. R. Tyler (Eds.), Trust in organizations: Frontiers of theory and research (pp. 216 -244). Thousand Oaks, CA: Sage.

Landy, F. J., \& Farr, J. L. (1980). Performance rating. Psychological Bulletin, 87, 72107.

Lincoln, J. R., \& Miller, J. (1979). Work and friendship ties in organizations: A comparative analysis of relational networks. Administrative Science Quarterly, 24, 181-199.

Lord, C. G., Ross, L., \& Lepper, M. R. (1979). Biased assimilation and attitude polarization: The effects of prior theories on subsequently considered evidence. Journal of Personality and Social Psychology, 37, 2098 -2109.

March, J. G. (1979). The technology of foolishness. In J. G. March \& J. P. Olson (Eds.), Ambiguity and choice in organizations (2nd ed., pp. $69-81$ ). Oslo, Norway: Universitetsforlaget.

Masterson, S. S. (2001). A trickle-down model of organizational justice: Relating employees' and customers' perceptions of and reactions to fairness. Journal of Applied Psychology, 86, $594-604$.

Masterson, S. S., Lewis-McClear, K., Goldman, B. M., \& Taylor, M. S. (2000). Integrating justice and social exchange: The differing effects of fair procedures and treatment on work relationships. Academy of Management Journal, 43, 738 749. 
Mathieu, J. E., \& Zajac, D. (1990). A review and meta-analysis of the antecedents, correlates, and consequences of organizational commitment. Psychological Bulletin, 108, 171-194.

Maume, D. J. (1999). Glass ceilings and glass escalators: Occupational segregation and race and sex differences in managerial promotions. Work and Occupations, 26, 483-509.

Mayer, R. C., Davis, J. H., \& Schoorman, F. D. (1995). An integrative model of organizational trust. Academy of Management Review, 20, 709 -734.

McPherson, J. M., \& Smith-Lovin, L. (1987). Homophily in voluntary organizations: Status distance and the composition of face-to-face groups. American Sociological Review, 52, $370-379$.

Meglino, B. M., \& Ravlin, E. C. (1998). Individual values in organizations: Concepts, controversies, and research. Journal of Management, 24, 351-389.

Meyer, J. P., \& Allen, N. J. (1997). Commitment in the workplace: Theory, research, and application. Thousand Oaks, CA: Sage.

Meyer, J. W., \& Rowan, B. (1977). Institutionalized organizations: Formal structure as myth and ceremony. American Journal of Sociology, 83, 340 -363.

Mowday, R. T., Steers, R. M., \& Porter, L. W. (1979). The measurement of organizational commitment. Journal of Vocational Behavior, 14, 224 -247.

Murguia, E., \& Telles, E. E. (1996). Phenotype and schooling among Mexican Americans. Sociology of Education, 69, $276-289$.

Niehoff, B. P., \& Moorman, R. H. (1993). Justice as a mediator between methods of monitoring and organizational citizenship behavior. Academy of Management Journal, 36, 527-556.

Oliver, R. L., \& Burke, R. R. (1999). Expectation processes in satisfaction formation: A field study. Journal of Service Research, 1, $196-214$.

O'Reilly, C., Caldwell, D. F., \& Barnett, W. (1989). Work group demography, social integration, and turnover. Administrative Science Quarterly, 34, 21-37.

Perry, E. L., Kulik, C. T., \& Zhou, J. (1999). A closer look at the effects of subordinatesupervisor age differences. Journal of Organizational Behavior, 20, 341-357.

Pfeffer, J. (1992). Managing with power: Politics and influence in organizations. Boston: Harvard Business School Press.

Riordan, C. M., \& Shore, L. M. (1997). Demographic diversity and employee attitudes: An empirical examination of relational demography within work units. Journal of Applied Psychology, 82, 342-358.

Robinson, S. L. (1996). Trust and breach of the psychological contract. Administrative Science Quarterly, 41, 574-599.

Rousseau, D. M. (1995). Psychological contracts in organizations: Understanding written and unwritten agreements. Thousand Oaks, CA: Sage.

Rousseau, D. M., \& McLean Parks, J. (1993). The contracts of individuals and organizations. In L. Cummings \& B. Staw (Eds.), Research in organizational behavior (Vol. 15, pp. 1- 43). Greenwich, CT: JAI Press. Rousseau, D. M., \&

Schalk, R. (2000). Learning from cross-national perspectives on psychological contracts. 
In D. M. Rousseau \& R. Schalk (Eds.), Psychological contacts in employment: Cross-national perspectives (pp. 283-304). Thousand Oaks, CA: Sage.

Schminke, M., Ambrose, M. L., \& Cropanzano, R. S. (2000). The effect of organizational structure on perceptions of procedural fairness. Journal of Applied Psychology, 85, $294-304$.

Schminke, M., Ambrose, M. L., \& Noel, T. W. (1997). The effect of ethical frameworks on perceptions of organizational justice. Academy of Management Journal, 40, $1190-1207$.

Shapiro, D. L., \& Kirkman, B. L. (1999). Employees' reaction to the change to work teams: The influence of "anticipatory" injustice. Journal of Organizational Change Management, 12, 51- 66.

Sherif, M., Harvey, O. J., White, B. J., Hood, W. R., \& Sherif, C. W. (1961). Intergroup cooperation and conflict: The robbers cave experiment. Norman: University of Oklahoma Book Exchange.

Sherif, M., \& Hovland, C. (1961). Social judgment: Assimilation and contrast effects in communication and attitude change. New Haven, CT: Yale University Press.

Shore, L. M., Tetrick, L. E., Taylor, M. S., Coyle-Shapiro, J. A., Liden, R. C., et al. (2004). The employee-organization relationship: A timely concept in a period of transition. Research in Personnel and Human Resources Management, 23, 291370.

Simons, T. (1999). Behavioral integrity as a critical ingredient for transformational leadership. Journal of Organizational Change Management, 12, 89 -104.

Simons, T. (2002). Behavioral integrity: The perceived alignment between managers' words and deeds as a research focus. Organization Science, 13, 18 -35.

Simons, T., \& McLean-Parks, J. (2000, August). The sequential impact of behavioral integrity on trust, commitment, discretionary service behavior, customer satisfaction, and profitability. Paper presented at the annual meeting of the Academy of Management, Toronto, Ontario, Canada.

Simons, T., \& Roberson, Q. (2003). Why managers should care about fairness: The effects of aggregate justice perceptions on organizational outcomes. Journal of Applied Psychology, 88, 432- 443.

Syphilis Study Legacy Committee. (1996). Bad blood: Final report of the Tuskegee Syphilis Study Legacy Committee [Abstract]. Retrieved October 8, 2002, from http://hsc.virginia.edu/hs-library/historical/apology/ report.html

Tajfel, H., \& Turner, J. C. (1986). The social identity theory of intergroup behavior. In S. Worchel \& W. G. Austin (Eds.), Psychology of inter-group relations (pp. 724). Chicago: Nelson-Hall.

Tang, J. (1993). The career attainment of Caucasian and Asian engineers. The Sociological Quarterly, 34, 467- 496.

Tate, G. (1996, November). Hypocrisy rife in company ethics. IRS Employment Trends, $619,2$.

Tett, R. P., \& Meyer, J. P. (1993). Job satisfaction, organizational commitment, turnover intention, and turnover: Path analysis based on meta- analytic findings. Personnel Psychology, 46, $259-293$. 
Thomas, D. A. (1989). Mentoring and irrationality: The role of racial taboos. Human Resource Management 28, 279 -290.

Triandes, H. C., Feldman, J., Weldon, D. E., \& Harvey, W. (1976). Eco-system distrust in the Black ghetto. In H. C. Triandes (Ed.), Variations in Black and White perceptions of the social environment (pp. 118 -132). Chicago: University of Illinois Press.

Tsui, A. S., Egan, T. D., \& O'Reilly, C. A. III. (1992). Being different: Relational demography and organizational attachment. Administrative Science Quarterly, $37,549-579$.

Tsui, A. S., \& O'Reilly, C. A. III. (1989). Beyond simple demographic effects: The importance of relational demography in superior- subordinate dyads. Academy of Management Journal, 32, 402- 423.

U.S. Department of Labor. (1992). Pipelines of progress: A status report on the glass ceiling. Washington, DC: U.S. Government Printing Office.

Van Maanen, J., \& Schein, E. H. (1979). Toward a theory of organizational socialization. In B. M. Staw (Ed.), Research in organizational behavior (Vol. 1, pp. 209 -264). Greenwich, CT: JAI Press.

Vecchio, R. P., \& Bullis, R. C. (2001). Moderators of the influence of supervisorsubordinate similarity on subordinate outcomes. Journal of Applied Psychology, $86,884-896$.

Wanous, J. P., Poland, T. D., Premack, S. L., \& Davis, K. S. (1992). The effects of met expectations on newcomer attitudes and behaviors: A review and meta-analysis. Journal of Applied Psychology, 77, 288-297.

Weick, K. E. (1995). Sensemaking in organizations. Thousand Oaks, CA: Sage.

Weiss, H. M. (1977). Subordinate imitation of supervisor behavior: The role of modeling in organizational socialization. Organizational Behavior and Human Performance, $19,89-105$.

Wesolowski, M. A., \& Mossholder, K. W. (1997). Relational demography in supervisorsubordinate dyads: Impact on subordinate job satisfaction, burnout, and perceived procedural justice. Journal of Organizational Behavior, 18, 351-362.

Williams, L. J., \& Anderson, S. E. (1994). An alternative approach to method effects using latent variable models. Journal of Applied Psychology, 79, 323-331.

Wilson, W. J. (1973). Power, racism, and privilege. New York: Macmillan.

Zenger, T. R., \& Lawrence, B. S. (1989). Organizational demography: The differential effects of age and tenure distributions on technical communication. Academy of Management Journal, 32, 353-376. 